\title{
Global Health Alarm of Oral Cancer
}

\author{
Sonu Kumar* \\ Tutor, Department of Public Health Dentistry, Kalka dental college \& hospital, India
}

Submission: October 30, 2017; Published: November 10, 2017

*Corresponding author: Sonu Kumar, Tutor, Department of Public Health Dentistry, Kalka dental college \& hospital, 2/1 kumar para lane, post office- Alambazar, Kolkata, State- West Bengal, Pin code 700035, India, Tel: +91 9557192716; Email: Sonu.dmf@gmail.com

\section{Editorial}

Oral cancer is a type of cancer which is seen in the oral cavity, which is usually, occurs with the use of tobacco (smoked and smokeless), alcohol and human papillomavirus (HPV). Oral cancer is fastest growing type of cancer worldwide, with the highest incident in the south East Asian region (mostly in India). About 2/3rd of cases diagnosed with advanced stages, due to ignorance toward oral health. Oral cancer collectively contributes to substantial morbidity and mortality rate globally. Incident remains high in developing country then developed country due to the more use of tobacco, tobacco with alcohol. As it affects oral along with general health, increased mortality as well as morbidity rate, premature death, increase health expenditure that's why it is global health alarm.

Global burden of oral health can be decrease by the followings

Life style modifications, yoga, meditation etc. awareness toward the oral health early diagnosis of pre-malignant lesions and conditions by the newly updated technique like vital staining, brush border biopsy, F.N.A.C.E etc. By cancer vaccination establishing oral cancer screening clinic in the rural and the in accessible areas worldwide making treatment of oral cancer affordable and accessible with the help of government policies, international health agencies, non-government organisations.

\section{Acknowledgement}

Thanks to my mother Smt. Sheela Devi, my father Dr. Ram Nagendra Sah. my Sisters Preeti and Jyoti Kumari, my best friend Dr. Ashish Kumar and my mentors Dr. Garima Sharma and Dr. Reenu sirohi for their guidance and support.

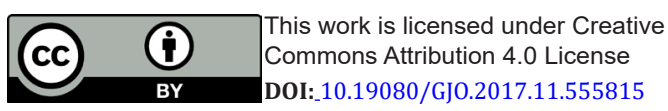

\section{Your next submission with Juniper Publishers} will reach you the below assets

- Quality Editorial service

- Swift Peer Review

- Reprints availability

- E-prints Service

- Manuscript Podcast for convenient understanding

- Global attainment for your research

- Manuscript accessibility in different formats ( Pdf, E-pub, Full Text, Audio)

- Unceasing customer service

Track the below URL for one-step submission https://juniperpublishers.com/online-submission.php 